\title{
Rhizobium Inoculation and Chemical Fertilisation Improve Faba Bean Yield and Yield Components in Northwestern Ethiopia
}

\author{
Getenesh Genetu $^{1}$, Markku Yli-Halla ${ }^{2, *}$, Mekonnen Asrat $^{3}$ and Mihiret Alemayehu ${ }^{3}$ \\ 1 Dangla District Agriculture Office, Dangla, Ethiopia; Geteneshgenetu21@gmail.com \\ 2 Department of Agricultural Sciences, University of Helsinki, 00014 Helsinki, Finland \\ 3 Department of Plant Science, Debre Markos University, Debre Markos P.O. Box 269, Ethiopia; \\ mek.asrat@yahoo.com (M.A.); mihralemayehu@gmail.com (M.A.) \\ * Correspondence: markku.yli-halla@helsinki.fi
}

Citation: Genetu, G.; Yli-Halla, M.; Asrat, M.; Alemayehu, M. Rhizobium Inoculation and Chemical

Fertilisation Improve Faba Bean Yield and Yield Components in Northwestern Ethiopia. Agriculture 2021, 11, 678. https://doi.org/ 10.3390/agriculture11070678

Academic Editor: Thomas F. Ducey

Received: 17 June 2021

Accepted: 16 July 2021

Published: 19 July 2021

Publisher's Note: MDPI stays neutral with regard to jurisdictional claims in published maps and institutional affiliations.

Copyright: (c) 2021 by the authors. Licensee MDPI, Basel, Switzerland. This article is an open access article distributed under the terms and conditions of the Creative Commons Attribution (CC BY) license (https:// creativecommons.org/licenses/by/ $4.0 /)$.

\begin{abstract}
The productivity of the faba bean has declined in Ethiopia, owing to poor management practices, such as blanket fertilisation. In 2018, a field experiment was conducted in a Nitisol soil during the main cropping season in Northwestern Ethiopia, to determine the amount of chemical fertiliser and Rhizobium inoculant to be used for the optimum yield within economic feasibility. The experiment consisted of a factorial combination of five rates of blended NPSZnB fertiliser $(0,60,121$, 180 and $\left.240 \mathrm{~kg} \mathrm{ha}^{-1}\right)$ and three rates of inoculant $\left(0,500\right.$ and $\left.750 \mathrm{~g} \mathrm{ha}^{-1}\right)$. Sole chemical fertilisation, as well as inoculation, individually produced a seed yield of $2.3-2.5 \mathrm{t} \mathrm{ha}^{-1}$, about $1.0-1.2 \mathrm{tha}^{-1}$ more than the control. However, the maximum seed yield $\left(3.3 \mathrm{tha}^{-1}\right)$ was recorded from the combined application of both the chemical fertiliser and the inoculant. The seed yield correlated closely with the number of active nodules $\left(\mathrm{R}^{2}=0.78^{* *}\right)$, suggesting a substantial contribution of symbiotic $\mathrm{N}_{2}$ fixation. Inoculation increased the $\mathrm{N}$ content of the seed yield by at least $30 \mathrm{~kg} \mathrm{ha}^{-1}$. Chemical fertilisation, containing at least $44 \mathrm{~kg} \mathrm{ha}^{-1}$ of mineral $\mathrm{N}$ does not appear to have an adverse effect on $\mathrm{N}_{2}$ fixation. The combined use of $180 \mathrm{~kg} \mathrm{ha}^{-1}$ blended fertiliser with $750 \mathrm{~g} \mathrm{ha}^{-1}$ inoculant, producing a maximum net profit of 72,918 birr ha $^{-1}$ (EUR 2232), is recommended for the study area. This study emphasises that (1) inoculation alone can produce as much seed as the maximum rate of chemical fertilisation, but (2) the maximum yield was produced with a combined use of inoculant and chemical fertiliser, by promoting the vigour of the nodules and $\mathrm{N}_{2}$ fixation.
\end{abstract}

Keywords: Rhizobium inoculant; leguminous crop; chemical fertilisation; biofertilizer; Dangla district

\section{Introduction}

The faba bean (Vicia faba L.) is a good source of protein, starch, cellulose and minerals, and is commonly used as human food in developing countries [1]. China, Ethiopia, Egypt, and the United Kingdom are the top producers of faba beans in the world. Ethiopia produces about $56 \%$ of the total faba bean output in Africa [2]. Faba bean is the third most important pulse, in terms of cultivated area and yield in the world, after soya bean and pea, while it is the most important pulse in Ethiopia [3,4]. In the 2019/20 cropping season, about 467,000 ha of land was cultivated for faba bean in Ethiopia, and 1006,752 tonnes of grain were obtained, of which about one third was produced in the Amhara region [4].

The productivity of faba beans in Ethiopia is very low-only $2.16 \mathrm{t} \mathrm{ha}^{-1}$ [4] -and even less than $1.0 \mathrm{ha}^{-1}$ in the study area, which is the Dangla district in the Amhara region. These numbers are much lower than the average yield in the rest of the world, which is approximately $4.8 \mathrm{t} \mathrm{ha}^{-1}$ [5]. The low yields in Ethiopia result from poor soil fertility management, along with other adverse factors, such as soil erosion, poor weeding practices, and the presence of different pests and diseases. Most highlands of Ethiopia are deficient in major essential nutrients, particularly nitrogen $(\mathrm{N})$ and phosphorus $(\mathrm{P})$. 
Soil inventory data of the Ethiopian Soil Information System revealed that the soils in Ethiopia are also deficient in potassium (K), sulphur (S), boron (B), and zinc (Zn) [6]. In the Amhara region, farmers are recommended to use $121 \mathrm{~kg} \mathrm{ha}^{-1}$ NPS fertiliser and $25 \mathrm{~kg} \mathrm{ha}^{-1}$ urea during crop planting [7]. However, farmers utilize amounts far below this blanket recommendation rate, due to economic constraints. In the low-input cropping systems of Ethiopia, chemical fertilisers are rarely used in the production of faba bean and other pulse crops. Instead, these crops are used to restore soil fertility for the succeeding cereal crops $[8,9]$.

In terms of $\mathrm{N}$ supply, leguminous crops can make use of Rhizobia, which are bacteria living symbiotically with legume crops, by fixing atmospheric $\mathrm{N}_{2}[10,11]$. Different leguminous crops require specific Rhizobium species for the formation of effective nodules and $\mathrm{N}_{2}$ fixation [12], and the various strains of Rhizobium species differ in their efficiency of $\mathrm{N}_{2}$ fixation [13]. The low level of nutrient supply and the lack of effective indigenous Rhizobium populations in soil have limited the faba bean yields [14]. Thus, the crop should be inoculated with the proper Rhizobium species and strains.

Inoculants can be regarded as biological fertilisers. They play a key role in crop productivity and may also protect the environment from pollution of leaching mineral $\mathrm{N}$ fertiliser residues, and serve as cost-effective inputs for farmers [15]. It has commonly been established that chemical $\mathrm{N}$ fertilisation of leguminous crops can substantially decrease the amount of $\mathrm{N}_{2}$ fixed from the air [16]. However, small amounts of $\mathrm{N}$ fertilisation can boost the early growth of crops, allowing the delivery of more carbohydrates for $\mathrm{N}_{2}$ fixation later in the season [17]. Diammonium phosphate (DAP) is a commonly available chemical fertiliser, so when it is used to provide the crop with $\mathrm{P}, \mathrm{N}$ is inevitably made available. Moreover, urea is often included in the blanket recommendation. Scarce information is available to the agricultural extension service, regarding the integrated use of Rhizobium inoculants and chemical fertiliser. Hence, this study was designed with the following objectives: (1) to investigate the characteristics of growth that are most affected by the additions of the chemical fertiliser and Rhizobium inoculant, (2) to evaluate the effects of the chemical fertilisation and Rhizobium inoculant rates on the growth and yield of the faba bean, and (3) to identify the economically feasible, optimum rates of chemical fertiliser and inoculant use to improve the faba bean yield in the Dangla district.

\section{Materials and Methods}

\subsection{Description of the Study Area}

The study was conducted in the main cropping season of 2018 at the Farmer Training Center (FTC) field of Wuftadati Kebele in the Dangila district, Awi Zone, Amhara National Regional State. The district is located $85 \mathrm{~km}$ southwest of Bahir Dar, the capital city of the Amhara region and $485 \mathrm{~km}$ northwest of Addis Ababa. The experimental site is located $10 \mathrm{~km}$ northwest of Dangla town, at an altitude of 2156 metres above sea level (masl) and with the geographical location at $11^{\circ} 14^{\prime} \mathrm{N}$ latitude, $33^{\circ} 45^{\prime} \mathrm{E}$ longitude.

The topography of the district is plain and the altitude ranges between 1353 and 2454 masl. Most of the Dangla district belongs to the Woinadega agro-ecological zone, which receives 700-1000 $\mathrm{mm}$ rainfall annually [18], and the rainfall pattern is mono-modal, extending from May to October. The mean monthly minimum and maximum temperatures are $15^{\circ} \mathrm{C}$ and $21^{\circ} \mathrm{C}$, respectively. Nitisols (red soils) are prevalent in most of the district $(80 \%)$, while the remaining $20 \%$ is occupied by Vertisols [18]. Soils of the Dangla district are the most degraded in the region, and they are very low in organic matter and plant nutrients, particularly N, P, K, S, B and Zn [6]. A mixed crop-livestock farming system is practiced in the area. The major crops grown in the district and the study site are cereals (maize, finger millet, teff, barley and wheat), legumes (faba bean, pea and chickpea) and oilseeds (noug, lentil and rape seed) in that order of importance [18]. During the experimental season, the mean monthly rainfall was $169 \mathrm{~mm}$, while the maximum and minimum temperatures were 27.3 and $3.5^{\circ} \mathrm{C}$, respectively (Figure 1). 


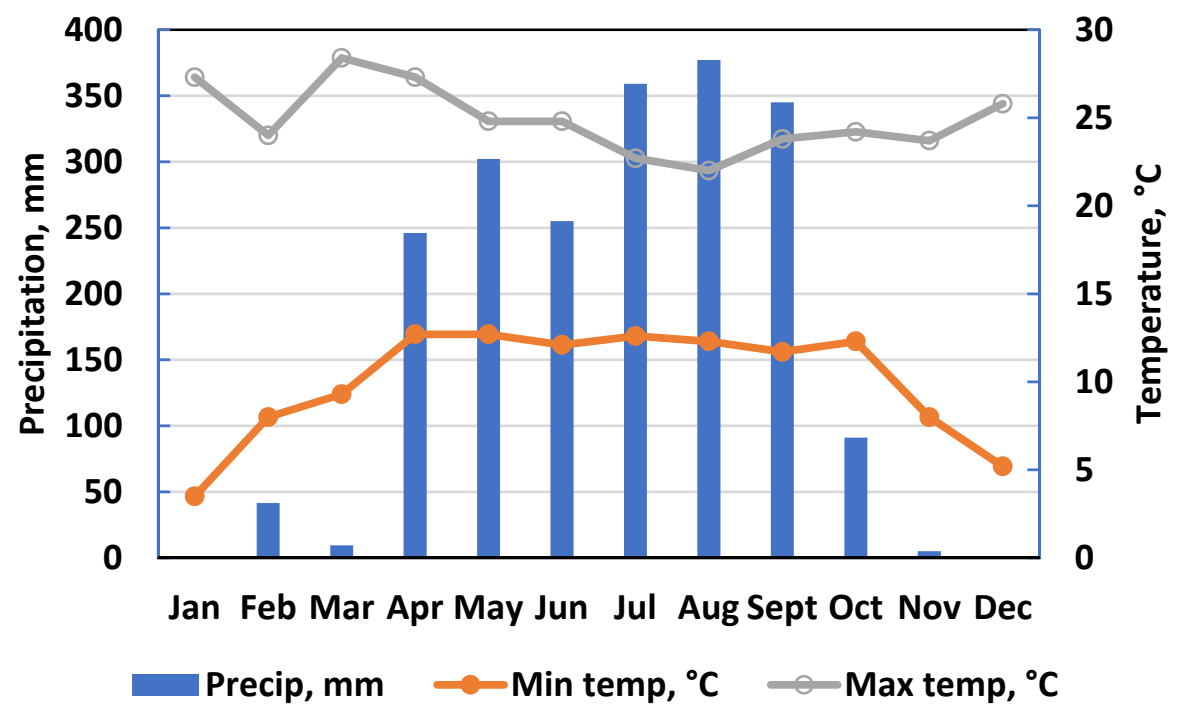

Figure 1. Mean monthly rainfall (Precip) and minimum (Min temp) and maximum temperature (Max temp) of the study area during the experimental season.

\subsection{Experimental Material, Treatments, Design and Procedures}

Faba bean of the Welki (EH96049-2) variety was used as the test crop. The variety was released in 2008 by the Holleta Agricultural Research Centre (HARC). It can grow at altitudes of 1900 to 2800 masl and requires 700 to $1000 \mathrm{~mm}$ annual rainfall. A blended chemical fertiliser with $17.8 \% \mathrm{~N}, 35.7 \% \mathrm{P}_{2} \mathrm{O}_{5}, 7.7 \% \mathrm{~S}, 2.2 \% \mathrm{Zn}$ and $0.1 \% \mathrm{~B}$ was used in the experiment, while a uniform amount of urea $(46 \% \mathrm{~N})$ was used as an additional source of N. Inoculants of Rhizobium leguminosarum biovar viceae, strain EL110 were collected from Menagesha Biotech, Addis Ababa. Lignite is used as the carrier in this commercial inoculant. Despite knowing that $\mathrm{K}$ deficiency can occur in the region [6] and that abundant $\mathrm{K}$ can positively affect the nodulation of faba bean [19], we chose not to use $\mathrm{K}$ fertilisation. Potassium is not included in the blanket fertiliser recommendation in the area, and we wanted to make an experiment as close as possible to the practical farming practices. Moreover, according to the expert knowledge, the local soils have at least a moderate $\mathrm{K}$ status.

Factorial combinations of five blended fertiliser rates $\left(0,60,121,180\right.$ and $\left.240 \mathrm{~kg} \mathrm{ha}^{-1}\right)$ and three inoculant rates $\left(0,500\right.$ and $\left.750 \mathrm{~g} \mathrm{ha}^{-1}\right)$, i.e., 15 treatment combinations, were laid out in a randomised complete block design (RCBD) and replicated three times (Table 1).

Table 1. Treatment combinations of the blended fertiliser and the inoculant for the experiment.

\begin{tabular}{cccccc}
\hline Inoculant, $\mathbf{~ h ~ h a ~}^{-\mathbf{1}}$ & \multicolumn{5}{c}{ Blended Fertiliser, $\mathbf{~ k g ~ h a - 1 ~}^{-\mathbf{1}}$} \\
\hline & 0 & 60 & 121 & 180 & 240 \\
\hline 0 & $0 \times 0$ & $0 \times 60$ & $0 \times 121$ & $0 \times 180$ & $0 \times 240$ \\
500 & $500 \times 0$ & $500 \times 60$ & $500 \times 121$ & $500 \times 180$ & $500 \times 240$ \\
750 & $750 \times 0$ & $750 \times 60$ & $750 \times 121$ & $750 \times 180$ & $750 \times 240$ \\
\hline
\end{tabular}

The predetermined amount of blended fertiliser, urea and the inoculant were utilised during crop sowing. A uniform rate of urea $\left(25 \mathrm{~kg} \mathrm{ha}^{-1}\right)$ was applied as a starter fertiliser. The nutrients added in the chemical fertilisers are presented in Table 2. 
Table 2. Amounts of nutrients, $\mathrm{kg} \mathrm{ha}^{-1}$, added at different levels in the blended chemical fertiliser and in urea.

\begin{tabular}{cccccc}
\hline Blended Fertiliser, kg ha $^{-\mathbf{1}}$ & $\mathbf{N}$ & $\mathbf{P}$ & $\mathbf{S}$ & $\mathbf{Z n}$ & $\mathbf{B}$ \\
\hline 0 & 12 & 0 & 0 & 0 & 0 \\
60 & 22 & 9 & 5 & 1.3 & 0.06 \\
121 & 33 & 19 & 9 & 2.7 & 0.12 \\
180 & 44 & 28 & 14 & 4.0 & 0.18 \\
240 & 54 & 37 & 18 & 5.3 & 0.24 \\
\hline
\end{tabular}

The gross plot size was $2.4 \mathrm{~m} \times 2.4 \mathrm{~m}\left(5.76 \mathrm{~m}^{2}\right)$ while the net plot size was determined by excluding one outer row and $0.20 \mathrm{~m}$ of length from both sides of each plot as border

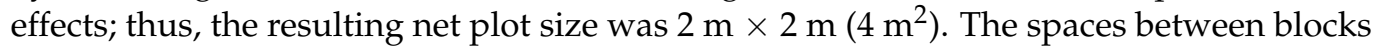
and plots were $1 \mathrm{~m}$ and $0.5 \mathrm{~m}$, respectively. The crop was planted in 6 rows on each plot with inter- and intra-row spacing of $40 \mathrm{~cm}$ and $10 \mathrm{~cm}$, respectively, and at a depth of $8 \mathrm{~cm}$ on 28 July 2018.

The experimental field, used recently for growing cereals, was ploughed three times by an oxen-driven local ploughing implement called maresha. The prepared land was further divided into plots as per the study design and levelled manually. The treatments were assigned randomly to the plots of each replication. The sticker material (sugar solution) was prepared by mixing $10 \mathrm{~g}$ of sugar with $100 \mathrm{~mL}$ of water. The sticker was used to evenly coat the seeds. One packet of the inoculum $(125 \mathrm{~g})$ was mixed with $200 \mathrm{~mL}$ of water to make a slurry. The seeds required for the plot were mixed in the slurry ensuring uniform coating of the inoculum over the seeds, with the target level at $10^{8}$ Rhizobium cells per seed. The seeds were dried under shade for about $30 \mathrm{~min}$ and sown within $24 \mathrm{~h}$. One packet of the inoculum $(125 \mathrm{~g})$ was sufficient to treat $10 \mathrm{~kg}$ of seed as per the recommendation. Weeds were controlled manually.

\subsection{Soil Sampling and Analysis}

Before sowing the crop, samples from the experimental soil were collected in a zigzag fashion from 9 spots at $0-30 \mathrm{~cm}$ depth. The subsamples were thoroughly mixed, and the composite soil sample was air dried and ground to pass through a $2 \mathrm{~mm}$ sieve for the analysis of texture, soil $\mathrm{pH}$, available $\mathrm{P}$ and cation exchange capacity (CEC). To determine total $\mathrm{N}$ and organic carbon, the soil was pulverised further to pass through a $0.5 \mathrm{~mm}$ sieve. The analyses were carried out by the soil chemistry and water quality section of Amhara Design and Supervision using standard methods and procedures.

Soil $\mathrm{pH}$ was determined using a digital $\mathrm{pH}$ metre at a 1:2.5 soil-to-water ratio [20]. The organic carbon content was determined by the Walkey and Black oxidation method [21]. The texture was determined by applying the hydrometer method [20]. The total $\mathrm{N}$ content was estimated through the Micro-Kjeldhal method [22]. The available $P$ was extracted with a $0.5 \mathrm{M} \mathrm{NaHCO}_{3}$ solution, $\mathrm{pH} 8.5$ [23]. The available $\mathrm{Zn}$ was extracted with diethylenetriaminepentaacetic acid-triethanolamine (DTPA-TEA) solution with $\mathrm{pH} 7.3$ [24]. CEC was determined by extracting the soil samples utilising ammonium acetate $\left(1 \mathrm{M} \mathrm{NH}_{4} \mathrm{OAc}, \mathrm{pH}\right.$ 7.0) followed by repeated washing with ethanol (96\%) to remove the excess ammonium $\left(\mathrm{NH}_{4}{ }^{+}\right)$ions. The adsorbed $\mathrm{NH}_{4}{ }^{+}$in the soil was displaced with sodium chloride and then determined by steam distillation and titration using $0.1 \mathrm{M} \mathrm{NaOH}$ [25].

\subsection{Data Collection and Analysis}

The phenological stage, growth and yield parameters were recorded to investigate the effects of the treatments, as indicated in Table 3 . The data collected from the experiment at different growth stages were subjected to statistical analysis (two-way ANOVA) as per the experimental design using SAS version 9.4. The mean separation was carried out using the least significant difference (LSD) test at $p<0.05$ [26]. The Pearson correlation coefficients were also calculated. Normal distribution of the data was confirmed using histograms and comparing the mean and median values. 
Table 3. Observations and measurements made from the crop.

\begin{tabular}{|c|c|c|}
\hline & Crop Data & Procedural Method of Recording \\
\hline 1 & $\begin{array}{l}\text { Days to emergence, flowering and } \\
\text { pod setting }\end{array}$ & $50 \%$ of the plants reaching the respective state by visual observation. \\
\hline 2 & Days to physiological maturity & $\begin{array}{l}90 \% \text { of the plants changing from green to yellowish, senescence of leaves and pod } \\
\text { colour turning black. }\end{array}$ \\
\hline 3 & No. of nodules per plant & $\begin{array}{l}\text { Randomly selected } 5 \text { plants per plot at } 50 \% \text { flowering uprooted and washed with wate; } \\
\text { nodules remaining in soil picked by hand. }\end{array}$ \\
\hline 4 & Effectiveness of nodules & $\begin{array}{l}\text { Nodules separated from the roots assessed by the interior colour; pinkish, brown and } \\
\text { reddish nodules considered effective while green, yellow and white classified as } \\
\text { ineffective in } \mathrm{N}^{2} \text { fixation. }\end{array}$ \\
\hline 5 & Nodulation rating & $\begin{array}{l}\text { Examining } 10 \text { plants with intact nodules for a) nodulation in the taproot (NPTRN), b) } \\
\text { the secondary roots close to taproot (NPNCTR), c) scattered all over the roots }(\mathrm{PSN}) \text { and } \\
\text { d) plants showing no nodulation }(\mathrm{PNN}) \text {; } \mathrm{N}=\text { total number of plants; the rating was } \\
\text { done on a scale of } 1-10 \text { and then subjected to the following formula for nodulation } \\
\text { rating (NR) (NifTAL, 1979):NR }=[(10 \times \mathrm{NPTRN})+(5 \times \text { NPNCTR })+(1 \times \mathrm{PSN})+ \\
(0 \times \mathrm{PNN})] / \mathrm{N}\end{array}$ \\
\hline 6 & Plant height & $\begin{array}{l}10 \text { randomly selected plants of each plot measured from soil surface to the tip of the } \\
\text { stem at } 90 \% \text { physiological maturity. }\end{array}$ \\
\hline 7 & No. of leaves per plant & Counting leaves of 5 randomly selected plants at $50 \%$ flowering. \\
\hline 8 & No. of productive tillers & $\begin{array}{l}\text { Counting fertile (productive) tillers arising from main stem from randomly selected } 10 \\
\text { plants at pod setting. }\end{array}$ \\
\hline 9 & $\begin{array}{l}\text { No. of pods per plant and seeds } \\
\text { per pod }\end{array}$ & Counting pods and seeds of 5 randomly selected plants from the middle rows at harvest. \\
\hline 10 & Yield (seed, biomass and straw) & $\begin{array}{l}\text { After threshing, seed was adjusted to } 14 \% \text { moisture content and weighed; total above } \\
\text { ground biomass from net plot was harvested and weighed; straw yield was obtained by } \\
\text { subtracting grain yield from total biomass yield. }\end{array}$ \\
\hline 11 & Hundred seed weight & Collecting and weighing 100 seeds from a selected plant \\
\hline 12 & Harvest index & Ratio of dry weight of grains to total aboveground biomass. \\
\hline
\end{tabular}

An economic analysis was performed using the CIMMYT partial budget methodology [27]. As usual, labour costs, chemical fertilisers and the inoculant were considered in the estimation of the variable cost while the prices of faba bean seeds and straw were employed to compute the field benefit of the treatments. The average field prices of faba bean seed and straw, chemical fertilisers, inoculant and labour were collected as per the proper time schedule during the experiment season. Accordingly, during the application season the price of blended fertiliser and inoculants were 15 birr kg ${ }^{-1}$ (EUR $0.46 \mathrm{~kg}^{-1}$ ) and 32 birr $100 \mathrm{~g}^{-1}$ (EUR $0.98100 \mathrm{~g}^{-1}$ ), respectively.

The labour cost for harvesting, threshing and winnowing was estimated at 100 birr per $100 \mathrm{~kg}$ seed yield (EUR $3.06 \mathrm{~kg}^{-1}$ ). The cost of seed packing material and transportation was 20 birr per $100 \mathrm{~kg}$ of seed (EUR $0.61 \mathrm{~kg}^{1}{ }^{1}$ ) while the cost of straw packaging and transporting was 10 birr (EUR 0.31) per $30 \mathrm{~kg}$. All the costs were computed to determine the total variable cost of treatment. The economic benefits of the treatment were computed by the estimated seed price of 24 birr kg-1 (EUR $0.73 \mathrm{~kg}^{-1}$ ) and straw price by $200 \mathrm{birr}$ $100 \mathrm{~kg}^{-1}$ (EUR $6.12100 \mathrm{~kg}^{-1}$ ). Then, a dominance analysis was undertaken to select the most profitable treatment option. The treatments were arranged in ascending order of total variable cost from the lowest to highest cost. Moreover, the net benefit of each treatment was computed through a difference of the gross field benefit to total cost. In the year of the experiment (2018), 100 birr was equivalent to EUR 3.06 or USD 3.61. 


\section{Results and Discussion}

\subsection{Physico-Chemical Properties of the Experimental Soil}

The experimental soil has a clay loam texture. The soil contained a total of $0.14 \% \mathrm{~N}$ and $11.9 \mathrm{mg} \mathrm{kg}^{-1}$ of available $\mathrm{P}$, representing the lower part of the medium P level, and $1.3 \mathrm{mg} \mathrm{kg}^{-1}$ of available $\mathrm{Zn}$ (Table 4). The $\mathrm{pH}$ was close to neutral, suggesting no problem with acidity or aluminium toxicity. The CEC of the soil was significantly low, and the $\mathrm{CEC}_{\text {clay, }}$, which was calculated to be $20.4 \mathrm{cmol}(+) \mathrm{kg}^{-1}$, was only half of what was reported in eight soils of the Farta district, central Ethiopia, which had an average clay content of $47 \%$ [28]. This suggests predominantly kaolinitic mineralogy in our experimental soil. The soil was tentatively classified as Eutric Nitisols according to the WRB system [29].

Table 4. Physicochemical properties of the experimental site's soil.

\begin{tabular}{ccc}
\hline Soil Parameters & Unit & Value \\
\hline Sand & $\%$ & 17 \\
Silt & $\%$ & 22 \\
Clay & $\%$ & 61 \\
Textural class & & Clay loam \\
pH & $\%$ & 6.96 \\
Organic C & $\%$ & 1.6 \\
Total N & $\mathrm{cmol}^{(+) \mathrm{kg}^{-1}}$ & 0.14 \\
CEC & $\mathrm{mg} \mathrm{kg}^{-1}$ & 18.0 \\
Available P & $\mathrm{mg} \mathrm{kg}^{-1}$ & 11.9 \\
Available Zn & & 1.3 \\
\hline
\end{tabular}

\subsection{Phenological Parameters}

The days to $50 \%$ emergence (data not shown) were similar for all the treatments, but the days to $50 \%$ flowering increased by 4 days at the maximum rate, with increasing amounts of blended fertiliser and inoculants (Table 5). It is noteworthy that the rate of blended fertiliser alone did not influence the early development of the faba bean and neither did the inoculation, but it was the combined application of both that had an effect. Similarly, the inoculant prolonged the days of $50 \%$ pod setting (data not shown) by about two days $(p<0.01)$, but the blended fertiliser did not have an effect. The number of days to physiological maturity was prolonged by the two treatments by four days at the maximum level (Table 5). The period between pod setting and physiological maturity was prolonged from 53 days in the control to 57 days in the plots receiving the maximum amounts of both amendments, thus allowing a few more days for pod filling.

Table 5. Days to 50\% flowering and days to maturity of faba beans that received different amounts of a blended chemical fertiliser and the Rhizobium inoculant.

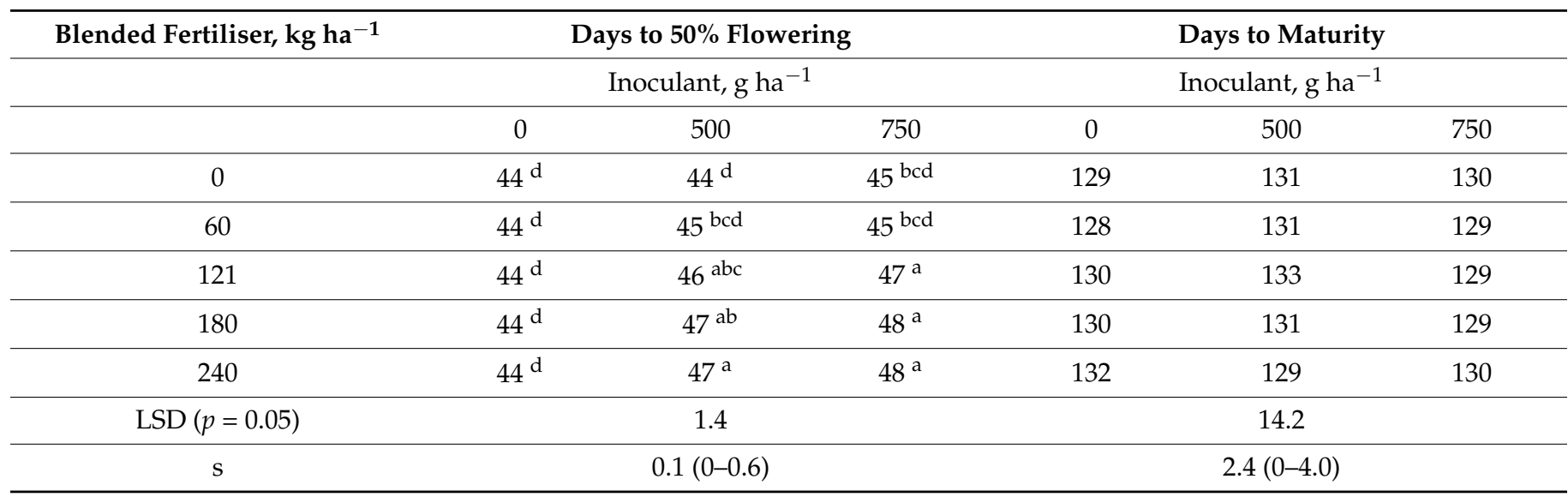

LSD $=$ Least Significant Difference at $p=0.05 ; \mathrm{s}=$ standard deviation expressed as a mean and range within individual treatments. The mean values of days to $50 \%$ flowering marked with the same letter are not significantly different at $p=0.05$. In the results of days to maturity, there were no significant differences. 
The abundant supply of nutrients from the blended fertilisers likely sped up early growth, which, in turn, enhanced the $\mathrm{N}_{2}$ fixation. Increased $\mathrm{N}$ supply usually delays the development of the stand and keeps it in the vegetative stage longer [30,31]. Such a positive response of shoot development, and the prolongation of the vegetative stage to inoculation and chemical $\mathrm{N}$ and/or P fertilisation, has also been reported for chickpea and common bean [32-34]. It has also been reported that increasing the $\mathrm{N}$ supply from 0 to $46 \mathrm{~kg} \mathrm{ha}^{-1}$ significantly prolongs the time to physiological maturity for the common bean [35].

\subsection{Vegetative Growth Parameters \\ 3.3.1. Nodulation}

The lowest numbers of nodules (54-56) were produced in plants receiving only chemical fertilisers. Even though the total nodulation did not increase with the fertiliser rate (Table 6), the number of active nodules increased from $19 \%$ to $70 \%$. Nodulation was greatly enhanced by inoculation, and the interaction effect of the inoculant and blended fertiliser was highly significant $(p<0.001)$. The highest numbers of nodules per plant $(130-140)$ were observed with the combined application of the inoculant and blended fertiliser at 121$240 \mathrm{~kg} \mathrm{ha}^{-1}$. However, the nodulation rating (range of 71-138 in the different treatments) was not significantly $(p>0.05)$ nor consistently influenced by any treatment. Around $60-70 \%$ nodules were active in the inoculated plants, except for the plants at a higher inoculation rate at 0 and $60 \mathrm{~kg} \mathrm{ha}^{-1}$ of blended chemical fertilisation. For an unknown reason, a large number of nodules developed in these plots, but only 20 or $30 \%$ of them were active.

Table 6. Total number of nodules and active nodules per plant as affected by blended fertiliser and inoculant rate.

\begin{tabular}{|c|c|c|c|c|c|c|}
\hline \multirow[t]{3}{*}{ Blended Fertiliser, $\mathrm{kg} \mathrm{ha}^{-1}$} & \multicolumn{3}{|c|}{ Total Number of Nodules } & \multicolumn{3}{|c|}{ Number of Active Nodules } \\
\hline & \multicolumn{3}{|c|}{ Inoculant, $\mathrm{g} \mathrm{ha}^{-1}$} & \multicolumn{3}{|c|}{ Inoculant, $\mathrm{g} \mathrm{ha}^{-1}$} \\
\hline & 0 & 500 & 750 & 0 & 500 & 750 \\
\hline 0 & $54^{\mathrm{e}}$ & $84^{\mathrm{d}}$ & $122^{b}$ & $10^{\mathrm{f}}$ & $47^{c}$ & 24 ef \\
\hline 60 & $55^{\mathrm{e}}$ & $87^{d}$ & $102^{c}$ & $15^{\mathrm{f}}$ & $63^{b}$ & $31^{\mathrm{ed}}$ \\
\hline 121 & $56^{\mathrm{e}}$ & $130^{a b}$ & $134^{\mathrm{a}}$ & $15^{\mathrm{f}}$ & $75^{\mathrm{ab}}$ & $83^{a}$ \\
\hline 180 & $58^{\mathrm{e}}$ & $133^{a}$ & $136^{\mathrm{a}}$ & $40^{\mathrm{cd}}$ & $83^{a}$ & $85^{\mathrm{a}}$ \\
\hline 240 & $56^{\mathrm{e}}$ & $133^{a}$ & $140^{\mathrm{a}}$ & $39 \mathrm{~cd}$ & $85^{\mathrm{a}}$ & $89^{\mathrm{a}}$ \\
\hline $\operatorname{LSD}(p=0.05)$ & \multicolumn{3}{|c|}{11.2} & \multicolumn{3}{|c|}{14.4} \\
\hline $\mathrm{s}$ & \multicolumn{3}{|c|}{$34(9-58)$} & \multicolumn{3}{|c|}{$17(2-30)$} \\
\hline
\end{tabular}

LSD $=$ Least Significant Difference at $p=0.05 ; \mathrm{s}=$ standard deviation expressed as a mean and range within individual treatments. The mean values within a given nodulation parameter marked with the same letter are not significantly different at $p=0.05$.

The inoculation of the faba bean crop has resulted in a higher number of effective nodules per plant compared to non-inoculated plants in other studies as well [34,36]. Particularly, the use of $\mathrm{P}$ along with the inoculant has increased the nodulation and $\mathrm{N}_{2}$ fixation of legume crops [37-39], as well as effective nodulation [40]. On the other hand, in some studies, $\mathrm{N}$ fertilisation of 60 and $90 \mathrm{~kg} \mathrm{ha}^{-1}$ led to decreased nodulation of the faba bean, while $30 \mathrm{~kg} \mathrm{ha}^{-1}$ had a positive effect compared to the control [39]. In our study, the effects of $\mathrm{N}$ and $\mathrm{P}$ could not be distinguished because both nutrients, as well as $\mathrm{S}, \mathrm{Zn}$ and $\mathrm{B}$, were utilised at increasing levels, with increasing additions of the blended chemical fertiliser. It is possible that the inhibitory effect of $\mathrm{N}$ on nodulation has been compensated for, or even outweighed by, the boosting effect of the increasing amounts of other nutrients, most likely $\mathrm{P}$, even though the level of available $\mathrm{P}$ in the soil was not low, but at the lower end of the medium range [22].

\subsubsection{Plant Height, Number of Leaves and Biomass Yield}

Plant height was significantly $(p<0.01)$ affected by the combined use of blended fertiliser and the inoculant (Table 7). The blended chemical fertiliser, when applied without inoculation, increased the plant height at the first level, but no further increase was observed 
with larger amounts. Notably, the inoculated plants were significantly taller than the ones without inoculation, only at the two highest levels of chemical fertilisation.

Similarly, the highest number of leaves (79) were observed in plots with the highest rates of blended fertiliser (180 and $240 \mathrm{~kg} \mathrm{ha}^{-1}$ ), while much fewer leaves (56) were observed in the control plot. Consequently, the total biomass yield consistently increased $(p<0.01)$, from the control $\left(5.1 \mathrm{tha}^{-1}\right)$ to the two highest levels of blended fertiliser rates (7.8 and $\left.8.3 \mathrm{tha}^{-1}\right)$.

Table 7. Plant height $(\mathrm{cm})$ affected by combined application of blended fertiliser and the inoculant.

\begin{tabular}{cccc}
\hline Blended Fertiliser & \multicolumn{3}{c}{ Inoculant, $\mathbf{g ~ h a}^{\mathbf{- 1}}$} \\
\hline $\mathrm{kg} \mathrm{ha}^{-1}$ & 0 & 500 & 750 \\
0 & $102^{\mathrm{f}}$ & $110^{\mathrm{ed}}$ & $102^{\mathrm{f}}$ \\
60 & $120^{\mathrm{e}}$ & $120^{\mathrm{e}}$ & $124^{\mathrm{cde}}$ \\
121 & $126^{\mathrm{cde}}$ & $120^{\mathrm{e}}$ & $136^{\mathrm{bcd}}$ \\
180 & $121^{\mathrm{ed}}$ & $139^{\mathrm{bc}}$ & $151^{\mathrm{ab}}$ \\
240 & $125^{\mathrm{cde}}$ & $156^{\mathrm{a}}$ & $157^{\mathrm{a}}$ \\
\hline LSD $(p=0.05)$ & & 15.8 & \\
$\mathrm{~s}$ & & $13.2(5.8-35)$ & \\
\hline
\end{tabular}

LSD $=$ Least Significant Difference at $p=0.05 ; \mathrm{s}=$ standard deviation expressed as a mean and range within individual treatments. The means marked with the same letter do not differ significantly at $p=0.05$.

\subsection{Yield-Related Parameters}

The number of productive tillers increased significantly $(p<0.01)$, from 1.3 to 3.0, with the increasing rate of blended fertiliser (Table 8). Rhizobium inoculation did not increase the number of productive tillers significantly, because the development stage when additional tillers are generated may have been passed before substantial $\mathrm{N}_{2}$ fixation occurred. It is quite evident that the increase in productive tillers was conducive to the increase in pods per plant. Rhizobium inoculation did not increase the hundred seed weight, but it was rather modestly increased by the blended fertiliser at application rates of $121-240 \mathrm{~kg} \mathrm{ha}^{-1}$ (Table 8).

Table 8. Number of productive tillers (NPT), pods per plant (NPP) and hundred seed weight (HSW) influenced by the main effects of the blended fertiliser and the inoculant.

\begin{tabular}{cccc}
\hline Treatments & NPT & NPP & HSW \\
\hline Blended fertiliser, $\mathrm{kg} \mathrm{ha}^{-1}$ & & & \\
0 & $1.3^{\mathrm{b}}$ & $9^{\mathrm{c}}$ & $59^{\mathrm{c}}$ \\
60 & $2.0^{\mathrm{b}}$ & $10^{\mathrm{c}}$ & $61^{\mathrm{bc}}$ \\
121 & $2.0^{\mathrm{b}}$ & $12^{\mathrm{b}}$ & $63^{\mathrm{ab}}$ \\
180 & $3.0^{\mathrm{a}}$ & $13^{\mathrm{ab}}$ & $67^{\mathrm{a}}$ \\
240 & $3.0^{\mathrm{a}}$ & $14^{\mathrm{a}}$ & $64^{\mathrm{ab}}$ \\
\hline LSD $(p=0.05)$ & 0.6 & 1.3 & 4.3 \\
\hline Inoculant $\left(\mathrm{g} \mathrm{ha}^{-1}\right)$ & $1.9^{\mathrm{b}}$ & & $62^{\mathrm{a}}$ \\
0 & $2.4^{\mathrm{a}}$ & $11^{\mathrm{c}}$ & $63^{\mathrm{a}}$ \\
500 & $2.1^{\mathrm{ab}}$ & $12^{\mathrm{a}}$ & $63^{\mathrm{a}}$ \\
750 & 0.5 & $13^{\mathrm{b}}$ & 3.3 \\
LSD $(p=0.05)$ & 0.5 & $2.5^{2}$ & 4.0
\end{tabular}

LSD = Least Significant Difference at $p=0.05 ; \mathrm{s}=$ standard deviation expressed as a mean within individual treatments. The mean values within a column marked with the same letter are not significantly different at $p=0.05$. The results of the different blended fertiliser rates and inoculant rates were tested separately.

The number of seeds per pod did not increase with the blended chemical fertiliser or the inoculant individually, but it increased significantly only with the combined application of the two highest rates of chemical fertiliser and inoculant (Table 9). Thus, there was a 
cumulative effect of increased nutrient supply to the plants, including a higher number of productive tillers and pods, which contained more and slightly heavier seeds per pod. These increases are additive, and contributed to a higher yield.

Table 9. Number of seeds per pod at different levels of blended chemical fertiliser and the inoculant.

\begin{tabular}{cccc}
\hline \multirow{2}{*}{ Blended Fertiliser, $\mathbf{k g ~ h a}^{-\mathbf{1}}$} & \multicolumn{3}{c}{${\text { Inoculant, } \mathbf{g ~ h a} \mathbf{~}^{\mathbf{1}}}$} \\
\cline { 2 - 4 } & $\mathbf{0}$ & $\mathbf{5 0 0}$ & $\mathbf{7 5 0}$ \\
\hline 0 & $2.3^{\mathrm{e}}$ & $2.7^{\mathrm{de}}$ & $2.3^{\mathrm{e}}$ \\
60 & $2.7^{\mathrm{de}}$ & $3.3^{\mathrm{cde}}$ & $3.0^{\mathrm{de}}$ \\
121 & $2.3^{\mathrm{e}}$ & $3.3^{\mathrm{cde}}$ & $3.3^{\mathrm{cde}}$ \\
180 & $2.7^{\mathrm{de}}$ & $3.7^{\mathrm{cd}}$ & $4.3^{\mathrm{bc}}$ \\
240 & $2.3^{\mathrm{e}}$ & $5.7^{\mathrm{a}}$ & $5.0^{\mathrm{bc}}$ \\
\hline $\operatorname{LSD}(p=0.05)$ & & 1.2 \\
$\mathrm{~s}$ & & $0.4(0-0.6)$ \\
\hline
\end{tabular}

LSD = least significant difference at $p=0.05 ; \mathrm{s}=$ standard deviation expressed as a mean and range within individual treatments. The means marked with the same letter do not differ significantly at $p=0.05$.

\subsection{Seed and Straw Yield and Harvest Index}

The seed yield (Table 10) was significantly $(p<0.01)$ affected by the main effects and interaction effects of the blended fertiliser and inoculant amounts (Figures 2 and 3). Blended fertiliser alone increased the yield consistently, by $89 \%$, from the control to the highest level of application, but the effect of inoculation was less consistent. Inoculation at the rate of $500 \mathrm{~g} \mathrm{ha}^{-1}$ increased the yield by $714 \mathrm{~kg} \mathrm{ha}^{-1}$, or $36 \%$ on average, compared to the yield obtained at a given level of blended fertilisation without inoculation (Figure 2). This increase can be attributed to the $\mathrm{N}$ provided to the plants via symbiotic $\mathrm{N}_{2}$ fixation. Inoculation alone seemed to produce a similar grain yield as the highest rates of blended fertiliser. The combined use of $180 \mathrm{~kg} \mathrm{ha}^{-1}$ blended fertiliser and 500-750 $\mathrm{g} \mathrm{ha}^{-1}$ inoculant gave the maximum seed yield of $3278-3325 \mathrm{~kg} \mathrm{ha}^{-1}$, which is around $800-900 \mathrm{~kg} \mathrm{ha}^{-1}$ more than with solely chemical fertilisation or inoculation.

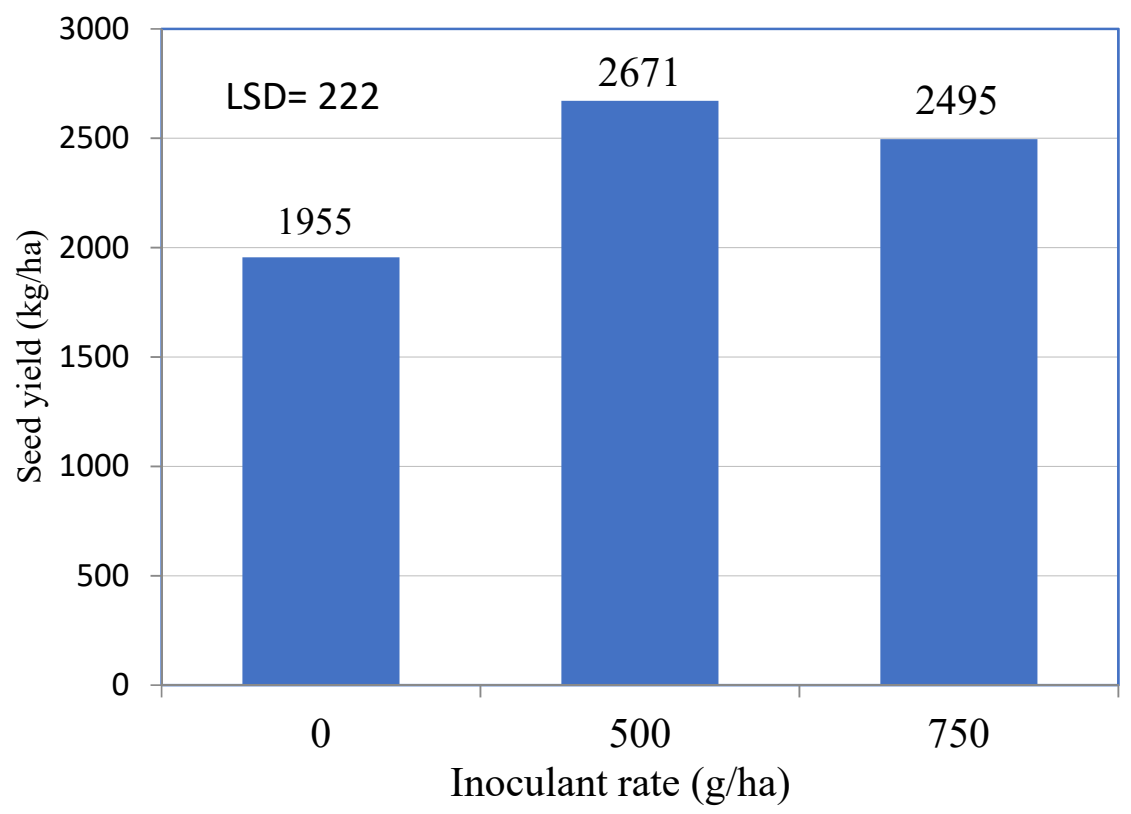

Figure 2. Effect of inoculant rates on seed yield of the faba bean.

Even though the seeds and straw were not analysed for N, we can estimate the effects of the two amendments on the $\mathrm{N}$ offtake by the crop, using the typical $\mathrm{N}$ concentrations of $3.15 \%$ for seeds and $0.82 \%$ for straw [41]. Hence, we can calculate that in the control, 
$69 \mathrm{~kg} \mathrm{ha}^{-1}$ (28 in straw and 41 in seeds) of $\mathrm{N}$ was assimilated, while the yield receiving the maximum rate of blended fertiliser contained $122 \mathrm{~kg} \mathrm{ha}^{-1}$ (44 in straw and 78 in seeds) of $\mathrm{N}$. The yield of the inoculated plots $\left(500 \mathrm{~g} \mathrm{ha}^{-1}\right)$ without the blended chemical fertiliser contained $34 \mathrm{~kg} \mathrm{ha}^{-1}$ ( 1 in straw and 33 in seeds) of $\mathrm{N}$ more than the control, while the maximum yield (inoculant $500 \mathrm{~g} \mathrm{ha}^{-1}$ and blended fertilizer) contained $143 \mathrm{~kg} \mathrm{ha}^{-1}$ (38 in straw and 105 in seeds) of $\mathrm{N}$, which is 28 ( -8 in straw and 36 in seeds) $\mathrm{kg} \mathrm{ha}^{-1}$ of $\mathrm{N}$ more than in the plots at the same level of chemical fertiliser but without inoculation. This calculation suggests that inoculation commonly resulted in the accumulation of over $30 \mathrm{~kg} \mathrm{ha}{ }^{-1}$ of $\mathrm{N}$ more than the seed yields from the plots without inoculation.

This finding, regarding the positive effect of chemical fertilisers on grain legume yield, is similar to several earlier findings. It has been established that inoculation along with P fertiliser has had a significant impact on nodulation, shoot dry matter, and grain yield on the faba bean [42]. The application of the P fertiliser and a small amount of $\mathrm{N}$ has significantly increased the economic yield of the faba bean [43], and the maximum common bean seed yield $\left(2160 \mathrm{~kg} \mathrm{ha}^{-1}\right)$ has been obtained from the utilisation of $23 \mathrm{~kg} \mathrm{ha}^{-1} \mathrm{~N}$ [33].

The higher rate of inoculation did not increase yield, with the application of 0 and $60 \mathrm{~kg} \mathrm{ha}^{-1}$ blended fertiliser, where the number of active nodules was low for unknown reasons, and thus the level of $\mathrm{N}_{2}$ fixation remained low. The straw yield of the crop ranged from 3.4 to $5.4 \mathrm{t}^{-1}$, and significantly $(p<0.01)$ increased with an increase in blended fertiliser; however, the other effects remained insignificant $(p>0.05)$.

Seed yield correlated positively with the days to flowering $(=0.58)$ and maturity $(=0.53)$, plant height $(=0.66)$, number of leaves per plant $(=0.62)$, productive tillers $(=0.59)$, pods per plant $(=0.72)$, and seeds per pod $(=0.55)$. It also correlated significantly with the total number of nodules $(=0.52)$, but more closely with the number of effective nodules $\left(=0.81\right.$ ) (Figure 4 ), indicating the important role $\mathrm{N}_{2}$ fixation plays in the $\mathrm{N}$ supply to the crop in this experiment. These correlation coefficients suggest that increased vegetative growth, either attained with the help of multi-nutrient chemical fertiliser or biological $\mathrm{N}_{2}$ fixation, contributes to higher faba bean yield. Almost all components of growth seem to be impacted.

The harvest index (Table 11) was not significantly affected by the use of the blended fertiliser, but it was affected by inoculation. The average harvest index for the inoculation rate of $500 \mathrm{~g} \mathrm{ha}^{-1}$ (40.0) was significantly higher than that for chemical fertilisation alone (31.9). There were differences in the levels of inoculation (Table 11). Again, at the inoculation rate of $750 \mathrm{~g} \mathrm{ha}^{-1}$, the applications of 0 and $60 \mathrm{~kg} \mathrm{ha}^{-1}$ blended fertiliser differed from the higher application rates, by having lower harvest indices. This result suggests that the increased supply of $\mathrm{N}$, as indicated by the number of active nodules, increases the proportion of seeds.

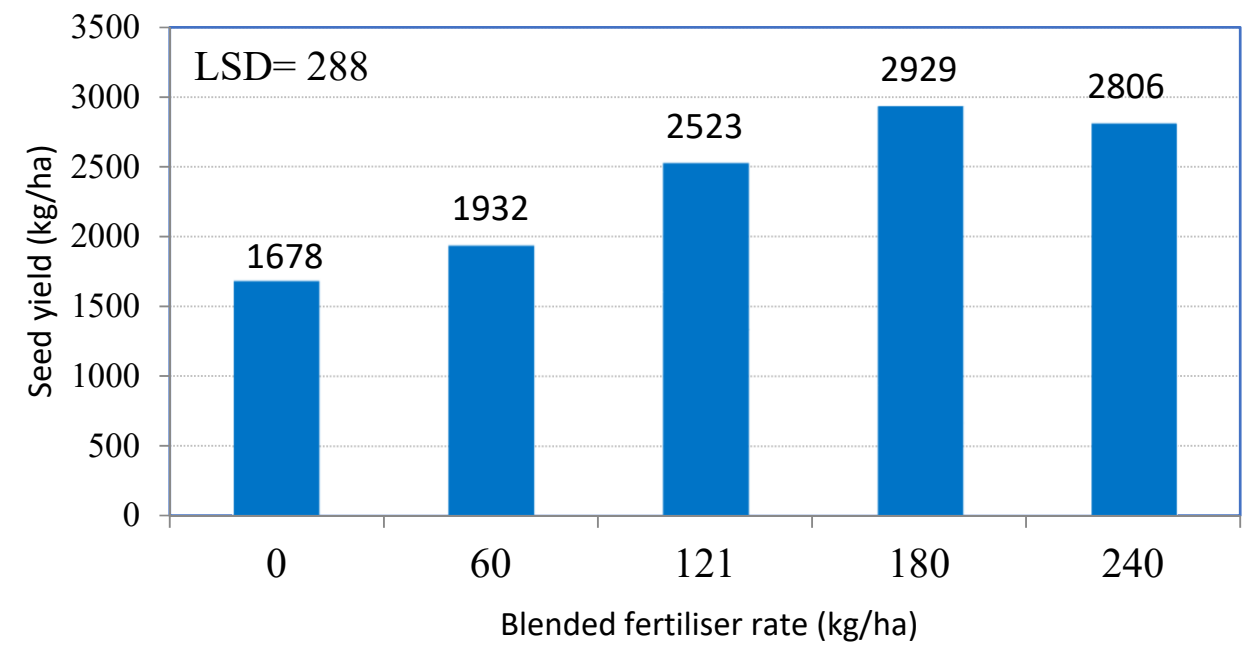

Figure 3. Effect of amounts of blended fertiliser on the faba bean seed yield. 


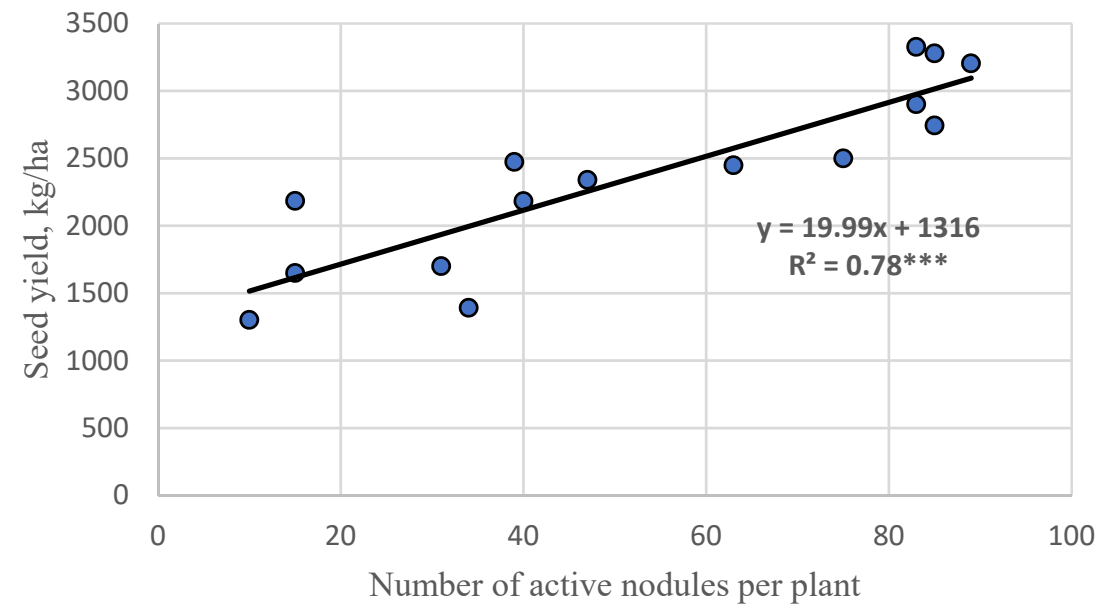

Figure 4. Relationship between the number of active nodules per plant and seed yield.

Table 10. The seed yields of faba bean receiving combed application of blended fertilizer and the inoculant.

\begin{tabular}{cccc}
\hline Blended Fertilizer Rate & \multicolumn{3}{c}{ Inoculant Rate, $\mathbf{g ~ h a}^{\mathbf{- 1}}$} \\
\hline $\mathbf{k g ~ h a}^{\mathbf{1}}$ & $\mathbf{0}$ & $\mathbf{5 0 0}$ & $\mathbf{7 5 0}$ \\
\hline 0 & $1302^{\mathrm{g}}$ & $2340^{\mathrm{de}}$ & $1391 \mathrm{~g}$ \\
60 & $1649^{\mathrm{g}}$ & $2447^{\mathrm{cde}}$ & $1700^{\mathrm{gf}}$ \\
121 & $2183^{\mathrm{ef}}$ & $2499^{\mathrm{cde}}$ & $2901^{\mathrm{abc}}$ \\
180 & $2183^{\mathrm{e}}$ & $3325^{\mathrm{a}}$ & $3278^{\mathrm{a}}$ \\
240 & $2473^{\mathrm{cde}}$ & $2743^{\mathrm{bcd}}$ & $3203^{\mathrm{ab}}$ \\
\hline LSD $(p=0.05)$ & & 498 \\
$\mathrm{~s}$ & $414(300-796)$ &
\end{tabular}

LSD $=$ Least Significant Difference at $p=0.05 ; \mathrm{s}=$ standard deviation expressed as a mean and range within individual treatments. The means marked with the same letter do not differ significantly at $p=0.05$.

Table 11. Harvest index as affected by combining blended fertiliser and inoculant.

\begin{tabular}{cccc}
\hline Blended Fertiliser & \multicolumn{3}{c}{ Inoculant, $\mathbf{g} \mathbf{h a}^{-\mathbf{1}}$} \\
\hline $\mathbf{k g ~ h a}^{\mathbf{- 1}}$ & $\mathbf{0}$ & $\mathbf{5 0 0}$ & $\mathbf{7 5 0}$ \\
\hline 0 & $32^{\mathrm{cdef}}$ & $40^{\mathrm{abcd}}$ & $29^{\mathrm{fg}}$ \\
60 & $29^{\mathrm{fg}}$ & $40^{\mathrm{abc}}$ & $25^{\mathrm{g}}$ \\
121 & $37^{\mathrm{abcdef}}$ & $37^{\mathrm{abcdef}}$ & $36^{\mathrm{bcdef}}$ \\
180 & $30^{\mathrm{efg}}$ & $45^{\mathrm{a}}$ & $36^{\mathrm{bcdef}}$ \\
240 & $31^{\mathrm{defg}}$ & $38^{\mathrm{abcde}}$ & $41^{\mathrm{ab}}$ \\
\hline $\operatorname{LSD}(p=0.05)$ & & 8.5 & \\
$\mathrm{~s}$ & & $5.6(1.7-12.1)$ &
\end{tabular}

LSD = Least Significant Difference at $p=0.05 ; \mathrm{s}=$ standard deviation expressed as a mean and range within individual treatments. The means marked with the same letter do not differ significantly at $p=0.05$.

\subsection{Economic Analysis}

The maximum net benefit of 72,918 birr ha ${ }^{-1}$ (EUR $2232 \mathrm{ha}^{-1}$ ), with an acceptable marginal rate of return (MRR) of $28 \%$, was recorded from the combined use of $180 \mathrm{~kg} \mathrm{ha}^{-1}$ blended fertiliser and $750 \mathrm{~g} \mathrm{ha}^{-1}$ inoculant, followed by the combined use of $180 \mathrm{~kg} \mathrm{ha}^{-1}$ blended fertiliser and $500 \mathrm{~g} \mathrm{ha}^{-1}$ inoculant (72,400 birr ha ${ }^{-1}$, or EUR $2216 \mathrm{ha}^{-1}$ ) (Table 12). The sole application of inoculants presented a lower yield as compared to the combined use of the inoculant with blended fertiliser. Thus, the combined application of $180 \mathrm{~kg} \mathrm{ha}^{-1}$ blended fertiliser and 500-750 $\mathrm{g} \mathrm{ha}^{-1}$ inoculant increased the net benefit the most. 
Table 12. An economic analysis of the experiment.

\begin{tabular}{|c|c|c|c|c|c|c|c|c|c|c|c|}
\hline SN & Treatmt & USeY & USwY & ASeY & ASwY & SeB & SwB & GB & TVC & NB & MRR \\
\hline 1 & $0 \times 0$ & 1302 & 3472 & 1172 & 3125 & 28,123 & 6250 & 34,373 & 2448 & 31,925 & \\
\hline 2 & $0 \times 750$ & 1391 & 3211 & 1252 & 2890 & 30,046 & 5780 & 35,825 & 2706 & 33,120 & 5 \\
\hline 3 & $0 \times 500$ & 2340 & 3559 & 2106 & 3203 & 50,544 & 6406 & 56,950 & 3755 & 53,195 & 19 \\
\hline 4 & $60 \times 0$ & 1649 & 4167 & 1484 & 3750 & 35,618 & 7501 & 43,119 & 3931 & $39,188^{\mathrm{D}}$ & \\
\hline 5 & $60 \times 750$ & 1700 & 3646 & 1530 & 3281 & 36,720 & 6563 & 43,283 & 4070 & $39,213^{\mathrm{D}}$ & \\
\hline 6 & $60 \times 500$ & 2447 & 3646 & 2202 & 3281 & 52,855 & 6563 & 59,418 & 4797 & 54,621 & 2 \\
\hline 7 & $121 \times 0$ & 2169 & 4514 & 1952 & 4063 & 46,850 & 8125 & 54,976 & 5512 & $49,464^{\mathrm{D}}$ & \\
\hline 8 & $121 \times 500$ & 2499 & 3646 & 2249 & 3281 & 53,978 & 6563 & 60,541 & 5768 & 54,773 & 1 \\
\hline 9 & $121 \times 750$ & 2901 & 4514 & 2611 & 4063 & 62,662 & 8125 & 70,787 & 6542 & 64,245 & 12 \\
\hline 10 & $180 \times 0$ & 2183 & 5643 & 1965 & 5079 & 47,153 & 10,157 & 57,310 & 6751 & $50,560^{\mathrm{D}}$ & \\
\hline 11 & $180 \times 500$ & 3325 & 4687 & 2993 & 4218 & 71,820 & 8437 & 80,257 & 7857 & 72,400 & 7 \\
\hline 12 & $240 \times 0$ & 2473 & 5382 & 2226 & 4844 & 53,417 & 9688 & 63,104 & 7885 & $55,219^{\mathrm{D}}$ & \\
\hline 13 & $240 \times 500$ & 2743 & 4861 & 2469 & 4375 & 59,249 & 8750 & 67,999 & 8181 & $59,818^{\mathrm{D}}$ & \\
\hline 14 & $180 \times 750$ & 3278 & 5729 & 2950 & 5156 & 70,805 & 10,312 & 81,117 & 8199 & 72,918 & 28 \\
\hline 15 & $240 \times 750$ & 3203 & 4688 & 2883 & 4219 & 69,185 & 8438 & 77,623 & 8706 & $68,918^{\mathrm{D}}$ & \\
\hline
\end{tabular}

UseY = Unadjusted Seed Yield in $\mathrm{kg} \mathrm{ha}^{-1}$; AseY = Adjusted Seed Yield in $\mathrm{kg} \mathrm{ha}^{-1}$; USwY = Unadjusted Straw Yield in $\mathrm{kg}^{-1}$; ASw $\mathrm{Y}=$ Adjusted Straw Yield in $\mathrm{kg} \mathrm{ha}^{-1} ; \mathrm{SeB}=$ Seed Benefit in birr ha ${ }^{-1}$; $\mathrm{SwB}=$ Straw Benefit in birr $/$ ha; GB $=\mathrm{Gross}_{\text {Benefit in birr ha }}{ }^{-1}$; TVC $=$ Total Variable Cost in birr ha ${ }^{-1} ;^{\mathrm{D}}=$ Dominated treatment; NB = Net Benefit in birr ha ${ }^{-1} ; \mathrm{MRR}=$ Marginal Rate of Return in $\%$.

\section{Conclusions and Recommendations}

Increasing amounts of blended NPSZnB fertiliser and Rhizobium inoculation, applied separately or together, had a significant influence on the yield components of the faba bean. An increase in the size of the photosynthetic machinery of the plant contributed to a higher seed yield. Higher numbers of productive tillers, tallest plants, and more nodules per plant increased the yields of seed, straw, and total biomass, indicating a positive impact of the increased nutrient supply. The seed yield was most closely correlated with the number of active nodules per plant, and there was a synergistic effect of chemical fertilisation and inoculation. Up to a level of $44 \mathrm{~kg} \mathrm{ha}^{-1} \mathrm{~N}$, we did not observe any adverse effect of mineral fertilisation on $\mathrm{N}_{2}$ fixation. The combined application of $180 \mathrm{~kg} \mathrm{ha}^{-1}$ blended fertiliser and 500-750 $\mathrm{g} \mathrm{ha}^{-1}$ inoculants resulted in the highest (3278-3325 kg ha-1) seed yield of the crop, which is approximately $800-900 \mathrm{~kg} \mathrm{ha}^{-1}$ more than the maximum obtained with chemical fertiliser or inoculation alone. It is obvious that the currently recommended blanket rate of fertilisation is too low to produce the optimum yields of the faba bean. Inoculation increased the $\mathrm{N}$ offtake in seeds by approximately more than $30 \mathrm{~kg} \mathrm{ha}^{-1}$.

According to the economic analysis, the combined use of blended fertiliser $\left(180 \mathrm{~kg} \mathrm{ha}^{-1}\right)$ with 500 or $750 \mathrm{~g} \mathrm{ha}^{-1}$ inoculant, presented the highest profit (around 73,000 birr ha ${ }^{-1}$, or EUR $2234 \mathrm{ha}^{-1}$, respectively), with an acceptable MRR, and they can be recommended for local farmers.

We are aware that these results cover only one experimental year. However, they show the effects of important phenomena of plant physiology. The positive effect of the combined use of moderate applications of chemical fertilisers and Rhizobium inoculation were demonstrated, even though the magnitude of the response can vary from year to year. Further empirical studies are required across locations and over different seasons, to make a comprehensive recommendation.

Author Contributions: Conceptualization, G.G., M.A. (Mekonnen Asrat); methodology, G.G., M.A. (Mekonnen Asrat); formal analysis, G.G., M.A. (Mekonnen Asrat); investigation, G.G., M.A. (Mekonnen Asrat), M.Y.-H.; writing—original draft preparation, G.G., M.A. (Mekonnen Asrat), M.A. (Mihiret Alemayehu); writing—review and editing, M.Y.-H.; visualization, G.G., M.A. (Mekonnen Asrat); supervision, M.A. (Mekonnen Asrat); project administration, M.A. (Mekonnen Asrat); funding acquisition, G.G. All authors have read and agreed to the published version of the manuscript.

Funding: This research was funded by the Debre Markos University as a partial fulfillment of Getenesh Genetu's MSc. study. 
Institutional Review Board Statement: Not applicable.

Informed Consent Statement: Not applicable.

Data Availability Statement: The data can be obtained upon request by e-mail to Mekonnen Asrat (mek.asrat@yahoo.com).

Conflicts of Interest: The authors declare no conflict of interest.

\section{References}

1. Giller, K.E. Nitrogen Fixation in Tropical Cropping Systems, 2nd ed.; CABI Publishing: Wallingford, UK, $2001 ;$ p. 448.

2. FAO (Food and Agricultural Organization of the United Nations). Statistical Pocket Book for World Food and Agriculture; FAO: Rome, Italy, 2014. Available online: http:/ / faostat3.fao.org/faostat-gateway (accessed on 14 June 2021).

3. Mihailovic, V.; Mikic, A.; Cupina, B.; Eric, P. Field pea and vetches in Serbia and Montenegro. Grain Legumes 2005, 44, 25-26.

4. CSA (Central Statistical Agency). Agricultural Sample Survey, Volume I, Report on Area and Production of Major Crops (Private Peasant Holdings, 20119/20 Meher Season), Statistical Bulletin 587; The Federal Democratic Republic of Ethiopia Central Statistical Agency: Addis Ababa, Ethiopia, 2015; p. 137.

5. Akibode, S.; Maredia, M. Global and Regional Trends in Production, Trade and Consumption of Food Legume Crops; Department of Agricultural, Food and Resource Economics, Michigan State University: East Lansing, MI, USA, 2012; p. 90.

6. EthioSIS (Ethiopia Soil Fertility Status). Fertilizer Recommendation Atlas of the Southern Nations; Ethiopian Government's Agricultural Transformation Agency: Addis Ababa, Ethiopia, 2014.

7. MoA (Ministry of Agriculture). Agricultural Extension Program Package; Ethiopian Institute of Agricultural Research (EIAR) and Agricultural Transformation Agency (ATA): Addis Ababa, Ethiopia, 2014; pp. 213-230.

8. Tilaye, A.; Bejiga, G.; Berhe, A. Role of cool season food legumes and their production constraints in Ethiopian agriculture. In Cool Season Food Legumes of Ethiopia, Proceedings of the First National Cool Season Food Legumes Review Conference, Addis Ababa, Ethiopia, 16-20 December 1993; Tilaye, A., Bejiga, G., Saxena, M.C., Sohl, M.B., Eds.; ICARDA: Aleppo, Syria, $1994 ;$ pp. 3-17.

9. Jida, M.; Assefa, F. Phenotypic and plant growth promoting characteristics1 Rhizobium leguminosarum biovar viciae from lentil growing areas of Ethiopia. Afr. J. Microbiol. Res. 2011, 5, 4133-4142.

10. Tena, W.; Wolde-Meskel, E.; Walley, F. Symbiotic efficiency of native and exotic Rhizobium strains nodulating lentil (Lens culinaris Medik.) in soils of southern Ethiopia. Agronomy 2016, 6, 11. [CrossRef]

11. Lindström, K.; Musavi, S.A. Effectiveness of nitrogen fixation in rhizobia. Microb. Biotechnol. 2020, 13, 1314-1335. [CrossRef]

12. Goss, M.J.; de Varennes, A.; Smith, P.S.; Ferguson, J.A. Nitrogen fixation by soybeans grown with different levels of mineral nitrogen, and the fertilizer replacement value for a following crop. Can. J. Soil Sci. 2002, 82, 139-145. [CrossRef]

13. Aserse, A.; Markos, D.; Getachew, G.; Yli-Halla, M.; Lindström, K. Rhizobial inoculation improves drought tolerance, biomass and grain yields of common bean (Phaseolus vulgaris L.) and soybean (Glycine max L.) at Halaba and Boricha in Southern Ethiopia. Arch. Agron. Soil Sci. 2020, 66, 488-501. [CrossRef]

14. Gorfu, D.; Mulugeta, W.; Keneni, G. Faba Bean Galls: A New Disease of Faba Bean in Ethiopia; Holeta Agricultural Research Center, Ethiopian Institute of Agricultural Research: Addis Ababa, Ethiopia, 2012.

15. Abera, T.; Feyssa, D.; Abebe, Z. A review of organic and biological soil fertility management integrated with NP on crops yield and soil fertility improvement in high and mid altitude areas of Western Oromia, Ethiopia. In Proceedings of the Improved Natural Resource Management Technologies for Food Security, Poverty Reduction and Sustainable Development, Addis Ababa, Ethiopia, 22-27 March 2009; Ethiopian Society of Soil Science, Ethiopian Institute of Agricultural Research: Addis Ababa, Ethiopia, 2010; pp. 38-45.

16. Hardarson, G.; Danso, S.K.A.; Zapata, F.; Reichardt, K. Measurements of nitrogen fixation in faba bean at different $\mathrm{N}$ fertilizer rates using the ${ }^{15} \mathrm{~N}$ isotope dilution and *A-value * methods. Plant Soil 1991, 131, 161-168. [CrossRef]

17. Mesfin, S.; Gebresamuel, G.; Haile, M.; Zenebe, A.; Desta, G. Mineral ferlilizer demand for optimum biological nitrogen fixation and yield potentials of legumes in Northern Ethiopia. Sustainability 2020, 12, 6449. [CrossRef]

18. DDAO (Dangla District Agriculture Office). Annual Report of 2018 Cropping Season; Dangla District of Agricultural Office Plan and Programme of Dangla: Awi Zone, Ethiopia, 2018; pp. 26-28.

19. Wojcieska, U.; Kocoñ, A. Reaction of faba bean plants to soil and foliar N application and K nutrition. Acta Physiol. Plant. 1997, 19, 23-28. [CrossRef]

20. FAO (Food and Agriculture Organization). FASTAT Database for Production of Pepper. 2009. Available online: http:/ / faostat.fao. org/site/3339/ default.aspx (accessed on 15 June 2021).

21. Sertus, S.; Bekel, T. Procedures for Soil and Plant Analysis; Technical Paper 74; National Soil Research Center: Addis Ababa, Ethiopia, 2000; p. 110.

22. Horneck, D.A.; Sullivan, D.M.; Owen, J.S.; Hart, J.M. Soil Test Interpretation Guide EC 1478; Oregon State University: Corvallis, OR, USA, 2011; p. 12.

23. Olsen, S.R.; Cole, C.V.; Watanabe, F.S.; Dean, L.A. Estimation of Phosphorus in Soils by Extraction with Sodium Bicarbonate; Circular 939; USDA: Washington, DC, USA, 1954; p. 19.

24. Lindsay, W.L.; Norvell, W.A. Development of a DTPA soil test for zinc, iron, manganese, and copper. Soil Sci. Soc. Am. J. 1978, 42, 421-428. [CrossRef] 
25. Hesse, P.R. A Text Book of Soil Chemical Analysis; John Murray Limited: London, UK, 1972; p. 470.

26. Gomez, K.A.; Gomez, A.A. Statistical Procedure for Agricultural Research, 2nd ed.; John Wiley and Sons. Inc.: New York, NY, USA, 1984; p. 680.

27. CIMMYT Economics Program. From Agronomic Data to Farmer Recommendations: An Economics Training Manual; Completely Revised Edition; CIMMYT: Mexico City, Mexico, 1988; p. 79.

28. Melese, A.; Gebrekidan, H.; Yli-Halla, M.; Yitaferu, B. Assessment of phosphorus status, inorganic phosphorus forms and other selected soil physicochemical properties of acid soils of Farta District Northwestern Highlands of Ethiopia. Appl. Environ. Soil Sci. 2015. [CrossRef]

29. IUSS Working Group WRB. World Reference Base for Soil Resources 2014. In World Soil Resources Reports; FAO: Rome, Italy, 2014; p. 181.

30. Arya, P.S.; Sagar, V.; Singh, S.R. Effect of NPK fertilizers on seed yield of French bean (Phaseolus vulgaris L.) var. Contender. Sci. Hortic. Engl. 1999, 6, 137-139.

31. Tewari, J.K.; Singh, S.S. Effect of nitrogen and phosphorus on the growth and seed yield of French bean (Phaseolus vulgaris L.). Veg. Sci. 2000, 27, 172-175.

32. Verma, J.P.; Yadav, J.; Tiwari, K.N.; Kumar, A. Effect of indigenous Mesorhizobium spp. and plant growth promoting rhizobacteria on yields and nutrients uptake of chickpea (Cicer arietinum L.) under sustainable agriculture. Ecol. Eng. 2013, 51, 282-286. [CrossRef]

33. Habete, A.; Buraka, T. Effect of Rhizobium inoculation and nitrogen fertilization on nodulation and yield response of common bean at Boloso Sore, Southern Ethiopia. J. Biol. Agric. Healthc. 2016, 6, 72-75.

34. Assefa, H.; Amsalu, B.; Tana, T. Response of common bean (Phaseolus vulgaris L.) cultivars to combined application of Rhizobium and NP fertilizer at Melkassa, Central Ethiopia. Int. J. Plant Soil Sci. 2017, 14, 1-10. [CrossRef]

35. Tadesse, N.; Dachassa, N. Effect of nitrogen and sulfur application on yield components and yield of common bean (Phaseolus vulgaris L.) in Eastern Ethiopia. Acad. Res. J. Agric. Sci. Res. 2017, 5, 77-89.

36. Denton, M.D.; Pearce, D.J.; Peoples, M.B. Nitrogen contributions from faba bean (Vicia faba L.) reliant on soil rhizobia or inoculation. Plant Soil 2013, 365, 363-374. [CrossRef]

37. Saini, V.K.; Bhandari, S.C.; Tarafdar, J.C. Comparison of crop yield, soil microbial C, N and P, N-fixation, nodulation and mycorrhizal infection in inoculated and no inoculated sorghum and chickpea crops. Field Crop. Res. 2004, 89, 39-47. [CrossRef]

38. Fatima, Z.; Zia, M.; Chaudhary, M.F. Interactive effect of Rhizobium strains and P phosphorus on soybean yield, nitrogen fixation and soil fertility. Pak. J. Bot. 2007, 39, 255-264.

39. Adak, M.S.; Kibritci, M. Effect of nitrogen and phosphorus levels on nodulation and yield components in faba bean (Vicia faba L.). Legume Res. 2016, 39, 991-994.

40. Yoseph, T. Effects of Rhizobium Inoculants and P Fertilization on Growth Yield and Yield Components of Haricot Bean at Umbullo Wacho Watershed, Southern Ethiopia; School of Plant and Horticultural Sciences, Hawassa University: Hawassa, Ethiopia, 2011.

41. Kubure, T.E.; Raghavaiah, C.V.; Arvind, C.; Hamza, I. Effect of faba bean (Vicia faba L.) genotypes, plant densities and phosphorus on productivity, nutrients uptake, soil fertility changes and economics in Central highlands of Ethiopia. Int. J. Life Sci. 2015, 3, 287-305.

42. Rifat, H.; Ali, S.; Siddique, M.; Chatha, T. Biological nitrogen fixation of summer legumes and their residual effects on subsequent rain fed wheat yield. Pak. J. Bot. 2008, 40, 711-722.

43. Agegnehu, G.; Fessehaie, R. Response of faba bean to phosphate fertilizer and weed control on Nitisols of Ethiopian highlands. J. Integr. Agric. 2006, 1, 281-290. [CrossRef] 